\title{
Pitfalls of gold mine sites in care and maintenance
}

\author{
AD Ashby Edith Cowan University, Australia \\ EJB van Etten Edith Cowan University, Australia
}

MA Lund Edith Cowan University, Australia

\begin{abstract}
Gold is a highly valued and volatile commodity which is subject to many external forces, such as price and availability. Global gold stocks are increasing but the supply is dwindling. Gold mining companies are always looking for novel methods to optimise extraction and processing thereby reducing operating costs and maximising profit. The extraction and processing of gold involves complex chemical processing which results in large volumes of waste, including toxic tailings, and damage to aquatic and terrestrial ecosystems. Our research indicates that gold mines in Western Australia regularly enter an operational phase known as 'care and maintenance' where active mining is not occurring but the site is not yet formally closed. It is a mode generally used to reduce operating costs and overheads, whilst maintaining the option to recommence mining in the future. Sites in care and maintenance are often neglected and minimal rehabilitation is undertaken resulting in massive environmental liabilities and social issues. In worst case scenarios, companies simply mothball the site and they become abandoned or legacy sites. We recently quantified the disturbance footprint and environmental legacies around a representative sample of gold mines in the West Australian Goldfields region. Our results suggest that sites in care and maintenance are a potential emerging problem for regulators left carrying the can for the costs of rehabilitation.
\end{abstract}

\section{Introduction}

Gold mining in Australia began in earnest with the first gold rush in southeastern Australia in the 1850s (Mudd 2007b) and operations rapidly popped up across Australia. Copper and gold were discovered in Coolgardie and Kalgoorlie in the 1890s (Mudd 2007b), mostly involving low grade oxidised deposits (La Brooy et al. 1994), these discoveries were vital in kick starting the Western Australia economy (Tonts et al. 2013). Following the unprecedented booms of the 1890s, gold production was relatively stable mainly due to the gold standard which aimed to control inflation. With the abandonment of the gold standard in the early 1970s, gold production in Australia generally rose, reaching a peak in 2000 of almost 200 tonnes per annum, before declining (Huleatt \& Jaques 2005). Production again rose to 180-190 tonnes per annum from 2010 to 2013, worth some AUD 8-9 billion per year (Tonts et al. 2013). Despite the general upward trend in production and price, gold remains a volatile commodity subject to huge price variations (Figure 1). For example, Australian gold producers were hit hard when prices slumped to record lows during the mid-1990s and many mines were closed, temporarily or permanently.

A number of practices have been adopted to combat the volatility in gold prices in the face of increasing resource scarcity. Firstly, investment in new technologies to improve efficiencies has occurred. For instance, new carbon-based technologies are capable of treating low grade ore of $\sim 1 \mathrm{~g} / \mathrm{t}$ (Salminen et al. 2015; Mudd 2007a; Huleatt \& Jaques 2005; La Brooy et al. 1994), and autonomous mining vehicles are capable of operating in extreme conditions (Owens 2013). Secondly, the size and scope of operations has increased to improve economies of scale, including amalgamating neighbouring gold mines. In some more extreme examples, mining gold at depths greater than 3,900 $\mathrm{m}$ is occurring at the TauTona gold mine in South Africa, whilst in Australia the Kalgoorlie superpit is now some 400 ha in area and approximately $600 \mathrm{~m}$ deep (ABC 2015). 


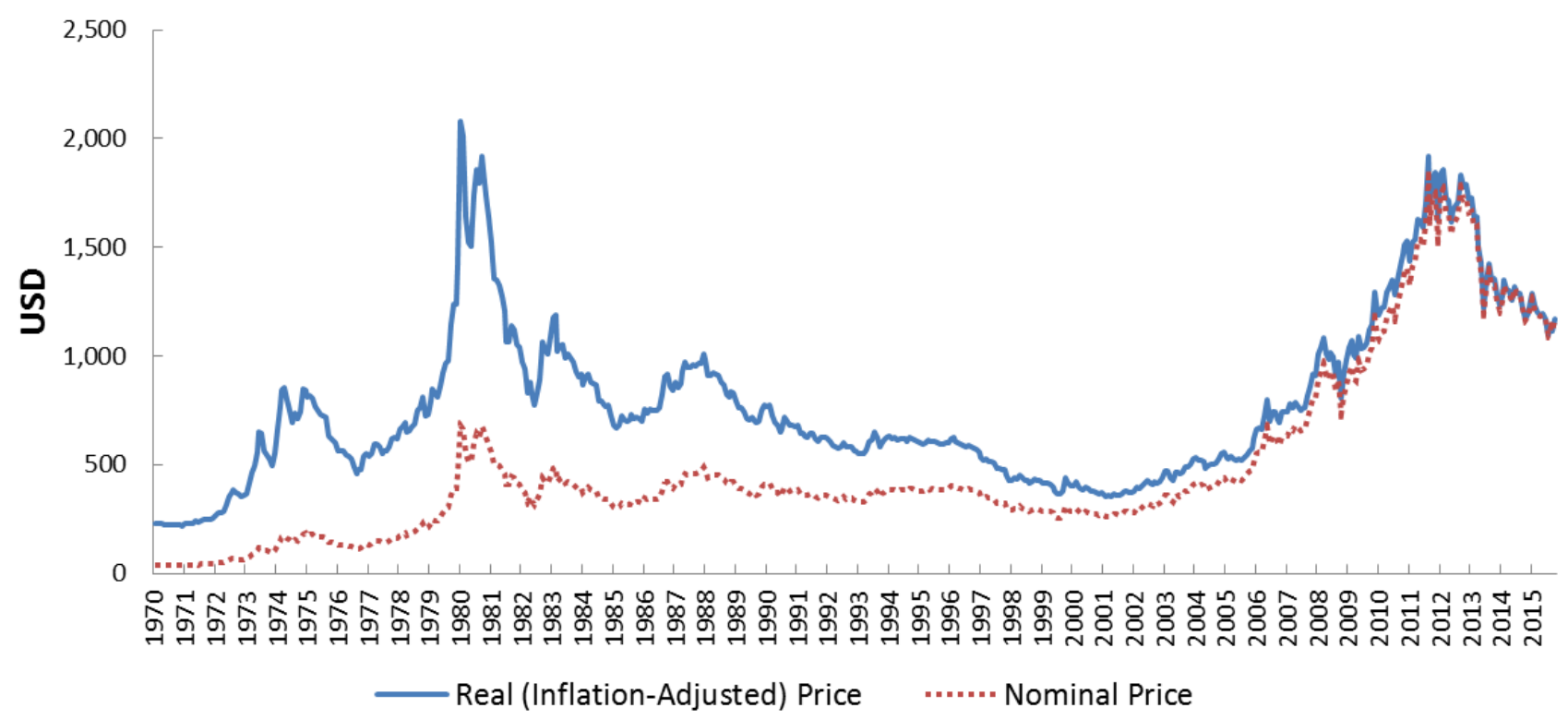

Figure 1 Trends in mean monthly gold price (real and nominal) in USD based on London Exchange values. Note: Real datasets are adjusted for inflation using the headline Consumer Price Index (CPI) with the current month (October 2015) as the base. Sources of data: London Bullion Market Association, Bureau of Labor Statistics, USA (MacroTrends 2015)

The third response is to opt for cruder (but cheaper) extraction techniques, such as heap leaching which involves designing structures (leach pads) and the application of cyanide solution to leach the metals from the mineral heap (White 1998; Figure 2).

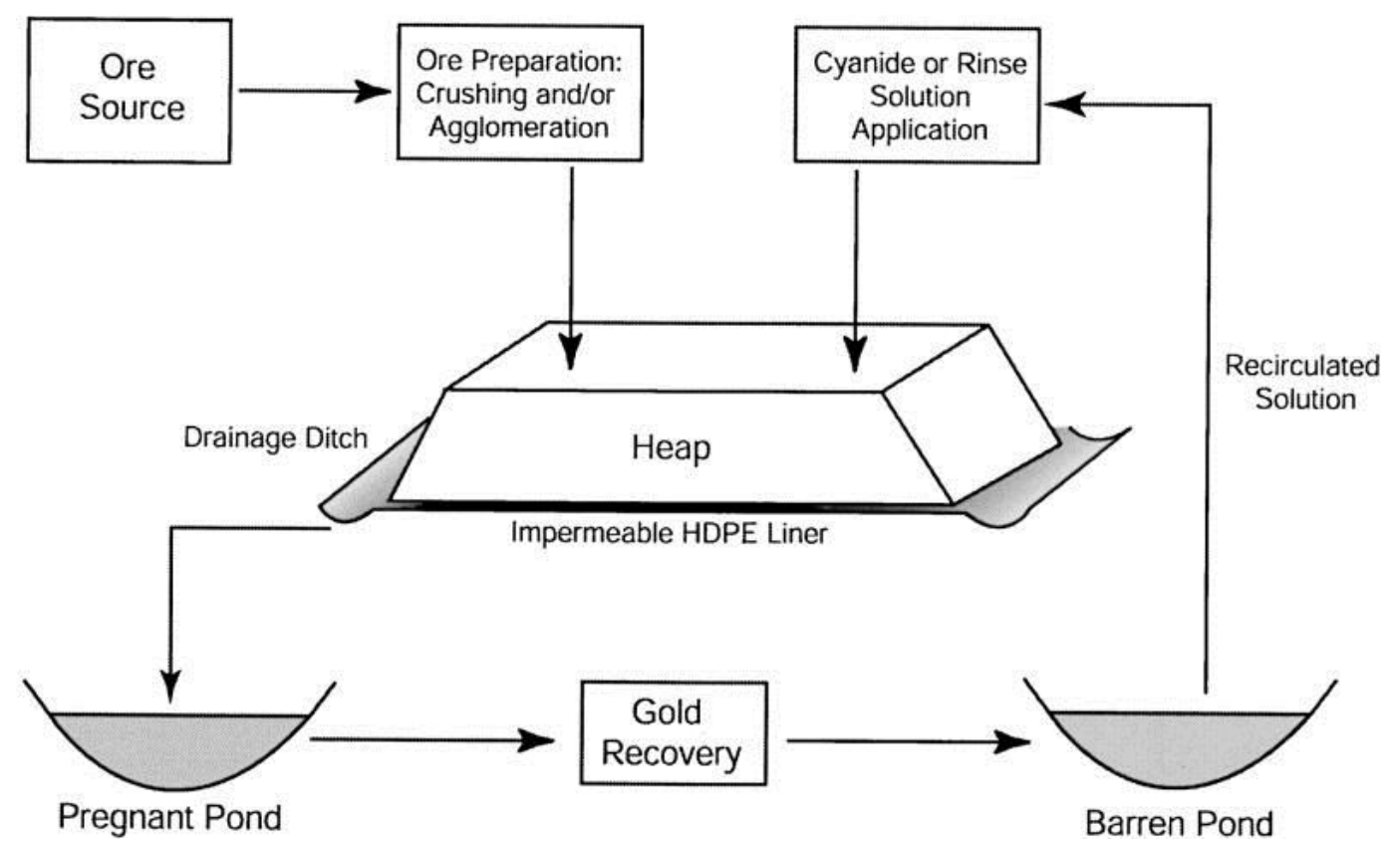

Figure 2 Example of heap leaching where a cyanide solution used to leach the metals such as gold (Kampf et al. 2002)

Although such measures increase efficiencies they also often result in more widespread and acute environmental impacts which require more money and technical know-how to manage effectively (Cooke \& Johnson 2002). Heap leaching technology, although designed to reduce overall crushing requirements and capital operating costs, potentially results in more soil contamination due to the ingress of rainwater (White 1998). Research by Curtis and Mousavi (2014) highlights the potential risks of using cyanide, due to its volatile and toxic nature, and states that even small amounts are toxic to animals and humans. 
Other mine related structures, namely tailings storage facilities (TSF) are also potential sources of pollution. In the goldfields regions of Western Australia, TSFs are ubiquitous structures and are often found at gold mines, with some as large as 300 ha in area (Smith et al. 2008). TSFs (Figure 3) often attract a wide range of vertebrate species, particularly birds as they appear to provide a food and water source (Smith et al. 2008), but this may result in poisoning of wildlife and livestock by cyanide-laced water (Griffiths et al. 2009). TSF, also have the potential to contaminate groundwater resources (Abdalla et al. 2010; Hilson 2002), particularly when gold mines are not active and operating in arid environments (Abdalla et al. 2010).

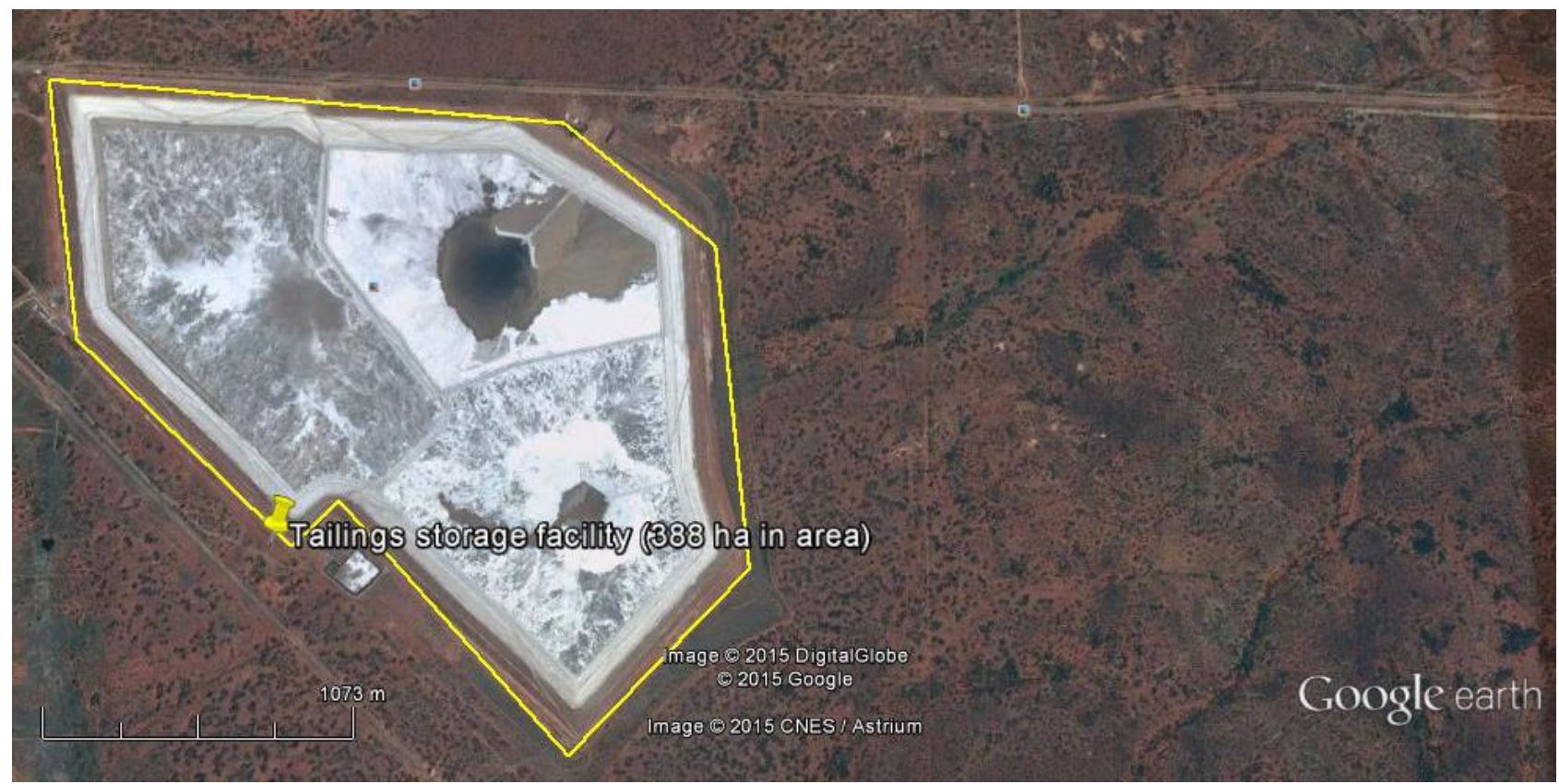

Figure 3 Google Earth (2015) Pro Image showing a TSF in goldfields of Western Australia. The area of this TSF is approximately 388 ha in area

The voids of open cut mines can interact with groundwater, resulting in marked changes in water quality whereby underground (stygofauna) communities can be impacted. Geotechnical issues may result whereby pit walls become unstable and significant risks are posed to fauna, stock and persons who may be in the vicinity of these structures (McCullough \& Lund 2006). The voids can become filled with water forming lakes. Other issues associated with mining include modification of surface water flows (Hilson 2002) and indirectly with significant clearing of and damage to vegetation leading to loss of habitat and impairment of ecological processes (Schueler et al. 2011). Furthermore, issues such as the pollution of soil or water resources, as a result of smelting and processing of ore, have been identified as serious environmental consequences of gold mining (Nobuntou et al. 2010).

Given the cyclic nature of the gold price and evolving extractive technologies and other practices to improve efficiencies of mining low grades, there is understandably reluctance to completely close mines when economic circumstances are unfavourable. Another option in such circumstances is to put mines in care and maintenance. Care and maintenance (C\&M) is a term used in the mining industry to describe processes and conditions on temporally closed mine sites where there is potential to recommence operations at a later date. During a C\&M phase, production is stopped but the site is required to be managed to ensure it remains in a safe and stable condition. There is limited empirical data and peer-reviewed literature around the relationship of gold price and gold mines entering C\&M. Further, little is known about the environmental consequences of leaving gold mines in C\&M. Long periods of C\&M potentially allow companies to postpone rehabilitation of sites which risks the site being abandoned and not rehabilitated when there is a change or relinquishment of ownership. In the case of abandonment, any legacies of the site effectively revert back to the state for remediation. The current systems, databases and frameworks utilised to capture and record sites in C\&M are also inadequate and need to be strengthened. 
Given the noted shortfalls in C\&M literature, spatial systems, databases and frameworks, we believe issues around C\&M warrant further investigation. Whilst it noted that $C \& M$ is a supposedly temporary alternative to mine closure in the gold industry in Western Australia, we here address the following questions: 1) how popular is the option of C\&M; 2) what are the key factors contributing to whether mines go to C\&M rather than full closure; 3 ) to what degree are mines in C\&M rehabilitated and where should rehabilitation be best directed in such circumstances; and 4) what are the implications of mines in C\&M in terms of mine closure legislation and policy, and for environmental performance and legacies?

\section{Methodology}

We obtained relevant mine site data and public information from various WA Department of Mines and Petroleum (DMP) databases and websites, particularly MINEDEX (DMP 2015). The data obtained from these sources was firstly arranged using Microsoft Excel in order of commodity, location and operational status and simple analyses were undertaken.

From this data, we extracted Western Australian mine sites in C\&M phase, as opposed to other mining stages such as 'operating', 'shut', 'proposed' and 'in development'. We then narrowed these down to gold mines and further to those with open pit mining, as opposed to shafts, surface scrapings and other forms of mining. For these open pit gold mines currently in C\&M (165 in total), we randomly selected 20 mines for site reconnaissance using remote sensing. Here we used Google Earth Pro to estimate the area of disturbance footprints (using the polygon feature of Google Earth) associated with each mining domain identified (including mine pits, waste dumps, tailings dams, lay down areas and general run of mine areas). Google Earth and associated imagery have been successfully used to assess and monitor mining impacts and the degree of mine rehabilitation (Emel et al. 2014; Sijinkumar et al. 2014; Kim et al. 2012). Only the immediate mining area was analysed with tracks/roads, exploration/seismic lines and infrastructure corridors which typically radiate from mine sites (Raiter et al. 2014) not included in the assessment. Only those sites which could be clearly demarcated from adjoining sites, via tenement maps and other visual features, and where the mine had entered C\&M stage at least three years before imagery in Google Earth (to allow time for rehabilitation), were selected for this spatial analysis using remote sensing.

In addition to measuring the area of disturbance footprint in each mining domain, we also measured areas which had achieved a reasonable degree of rehabilitation in each mining domain (and overall). This was done by visually demarcating areas where there was some discernible and reasonable cover of revegetation from areas which were bare or with very low (sparse) vegetative cover. We then calculated the area of the rehabilitated land as a percentage of each mining domain and overall. The assessment of disturbance footprint and rehabilitation were designed as preliminary analysis and limitations of the approach are acknowledged in that only crude estimates are possible; ideally field measurements should be done to validate the remotely-sensed information.

\section{$3 \quad$ Results and discussion}

\subsection{Current requirements and expectations for mines in care and maintenance}

The lifecycle of a mine site is complex and involves many phases (Figure 4); from exploration through to commencing mining (Ferguson et al. 2011). Upon cessation of mining and a scaling back in production, it is expected the company either commences rehabilitation or will commence progressive rehabilitation, which is shown in Figure 4 as 'closure' (Fourie \& Brent 2006). Finnie et al. (2009) suggest that, due to declining gold prices, environmental issues may potentially become exacerbated due to lack of funds. Gold mines can pose significant environmental issues when operational, at closure and even post-closure in all areas, internationally and potentially locally, due to the presence of TSFs (Pritchard et al. 2010; Finnie et al. 2009; Mudd 2007a). 

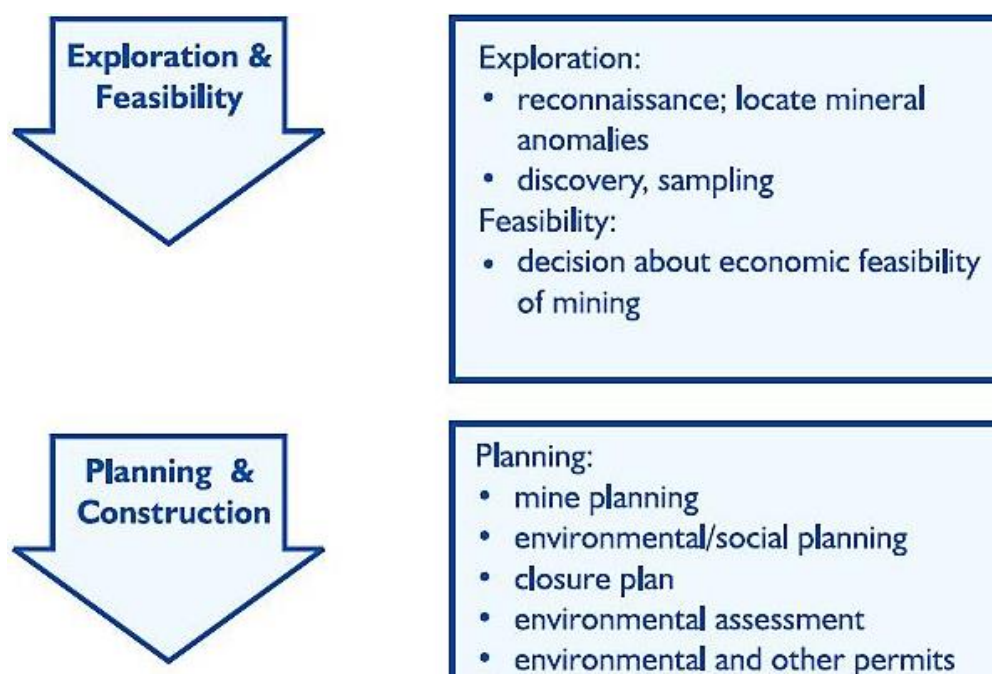

Planning:

- mine planning

- environmental/social planning

- closure plan

- environmental assessment

- environmental and other permits

Construction:

- clearing, stripping, blasting; infrastructure

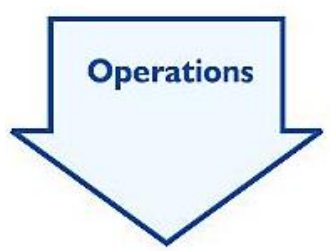

- ore extraction

- crushing, grinding, concentrating

- waste rock and tailings management

- wastewater management

- progressive reclamation

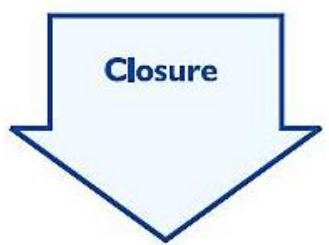

- site clean-up; reclamation; rehabilitation

- maintenance; environmental monitoring

Figure 4 Example of Mine Lifecycle (adapted from Environment Canada 2015)

At present when a mine site enters C\&M there is an expectation by the Western Australian regulator (Department of Mines and Petroleum) that environmental obligations are being met. For instance, as soon as possible, following placing the site in C\&M, an environment audit is carried out by the company to determine the status of landforms and infrastructures, for instance, waste landforms, TSFs, plant and pits (DMP 2009). A plan then can be developed to manage and mitigate any potential environmental issues such as erosion, seepage, groundwater contamination, acid rock drainage and pollution of the surrounding area (Gilbert \& Tobin Lawyers 2014). It is also noted that tenement conditions placed on the mine site still apply when the site is a C\&M phase, and the tenement holder must also continue to pay rent and meet expenditures otherwise the tenement may be subject to forfeiture by the Minister or any other person (Gilbert \& Tobin Lawyers 2014; DMP 2009).

\subsection{Current status and trends of mines in care and maintenance}

Across all types of mines and commodities, there are some 682 mine sites currently listed as under C\&M in Western Australia, which is about half the number currently operating - however this represents only a small proportion compared to shut mine sites (Table 1). This dataset covers all types of mines sites (from small shafts and scrappings to massive open pits) and a long time period, so it is not surprising it mainly comprises shut mines. 
Table 1 Number of mine sites in Western Australia (of all types) in various stages for each major commodity type and overall, as of September 2015 (data from DMP 2015)

\begin{tabular}{|c|c|c|c|c|c|c|c|c|}
\hline \multirow[t]{2}{*}{ Stage } & \multicolumn{6}{|c|}{ Commodity type } & \multirow{2}{*}{$\begin{array}{c}\text { All } \\
\text { mines }\end{array}$} & \multirow{2}{*}{$\begin{array}{c}\% \text { of } \\
\text { all } \\
\text { mines }\end{array}$} \\
\hline & $\begin{array}{l}\text { Base } \\
\text { metal }\end{array}$ & $\begin{array}{c}\text { Construction } \\
\text { material }\end{array}$ & $\begin{array}{c}\text { Industrial } \\
\text { mineral }\end{array}$ & $\begin{array}{l}\text { Iron/steel } \\
\text { alloy }\end{array}$ & $\begin{array}{l}\text { Precious } \\
\text { metals }\end{array}$ & $\begin{array}{l}\text { Speciality } \\
\text { metals }\end{array}$ & & \\
\hline $\begin{array}{l}\text { Care and } \\
\text { maintenance }\end{array}$ & 12 & 187 & 41 & 120 & 267 & 23 & 682 & 3.5 \\
\hline Operating & 9 & 590 & 68 & 221 & 337 & 16 & 1,283 & 6.7 \\
\hline Proposed & 10 & 138 & 19 & 203 & 192 & 26 & 625 & 3.2 \\
\hline Shut & 928 & 525 & 543 & 352 & 13,361 & 627 & 16,515 & 85.9 \\
\hline $\begin{array}{l}\text { Under } \\
\text { development }\end{array}$ & 4 & 47 & 1 & 43 & 32 & 5 & 132 & 0.7 \\
\hline Total & 963 & 1,487 & 672 & 939 & 14,189 & 697 & 19,237 & 100.0 \\
\hline
\end{tabular}

* Note gold is included under 'precious metals'

In terms of open pit gold mines, our main focus in this study, there are currently more mines in C\&M (165 sites or $8.5 \%$ ) than mines currently operating (3.9\%; Figure 5$)$, which suggests that C\&M is a more popular option in the gold mining industry than for other commodities (Table 1). The data also shows that there is a very large proportion (87\%) of open pit gold mines that are either shut or in C\&M phase (Figure 5). The data extracted from Public Minedex database is a general guide and may not be up-to-date as there will be some lag between approval of altered mine stage and data appearing in the database. Further, the terminology used, for instance shut and C\&M, could also potentially be ambiguous, and may not be giving an accurate representation of the current operating status of gold mines in Western Australia. For these reasons we advocate a more detailed investigation to quantify and confirm the number of sites in C\&M.

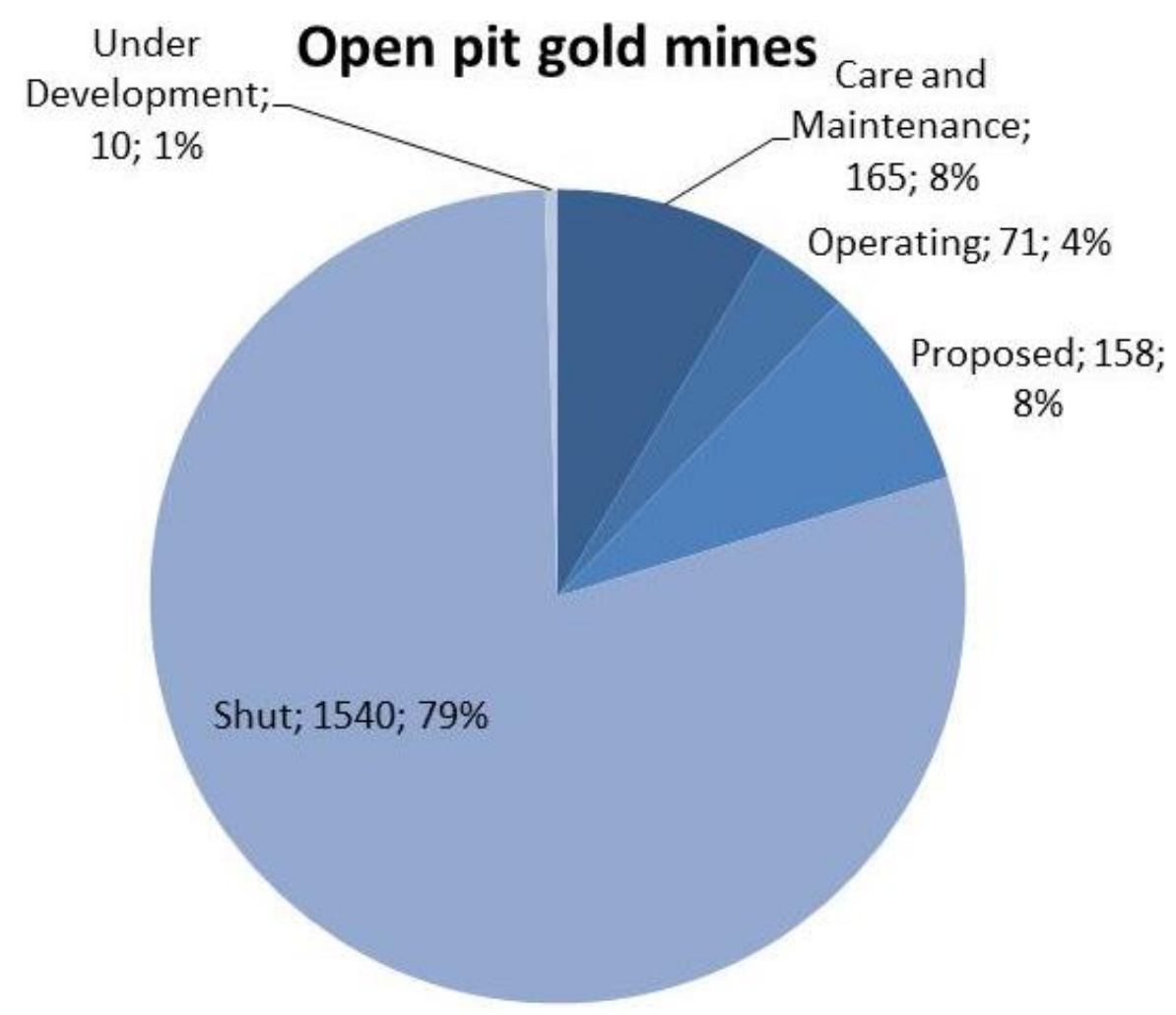

Figure 5 Number and percentage of open pit gold mines in Western Australia in various stages, as of September 2015 (data from DMP 2015) 
The number of open pit gold mines entering into C\&M varies widely from year to year (Figure 6). This data is based on the date given as the commencement of C\&M on the Public MINEDEX database which may be sometime after a company applies for a mine site to enter C\&M. Notwithstanding some lag effect, the overall trend is for more mines to enter the C\&M stage during times of lower gold price (Figure 1). For instance, the peak in mines entering C\&M, around 2000 (Figure 6), corresponds to 20 year low gold prices during this time (Figure 1; Fang et al. 2007). The peaks in C\&M around 2003-5 and 2007-2009 occurred at times of short-term reductions in the gold price even though this was time of general recovery (Figure 1). As the gold price was coming off a very low base during the 2000 s there was, understandably, some conservatism in mine planning at this time. The gold price peaked in early 2012 and since then few mines have entered C\&M.

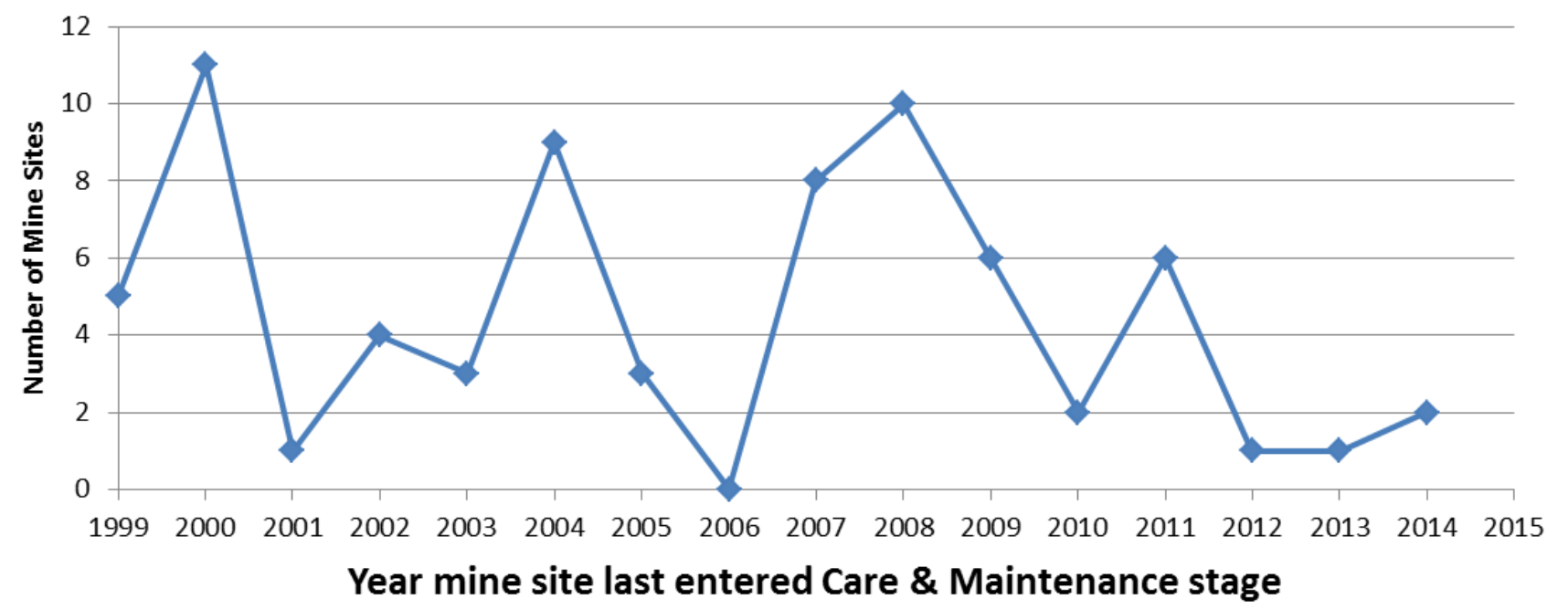

Figure 6 Number of open pit gold mine sites in Western Australia (out of a total of 74 selected randomly) entering the care and maintenance stage for each year since 1999. As some mines have had successive periods in C\&M, only the most recent C\&M conversion date has been used. Data extracted from DMP 2015

\subsection{Rehabilitation of mines in care and maintenance}

Our research shows that Google Earth Pro is a valuable spatial tool for undertaking preliminary desktop spatial analyses and determining the approximate disturbance footprint of gold mines in Western Australia, as others have found (Emel et al. 2014; Sijinkumar et al. 2014; Kim et al. 2012).

We found poor and/or incomplete rehabilitation at most of the 20 gold mine sites in C\&M we examined remotely, including those which had been closed for many years before the date of the imagery we used to assess condition and disturbance (Table 2). Nonetheless, we found a small number of sites (3) where there was good rehabilitation ( $>70 \%$ of disturbed land revegetated) - these were small, standalone sites which had been in C\&M for at least 10 years before assessment (Table 2). 
Table 2 Results of remote sensing of disturbance footprints and per cent rehabilitation (by area) for main mining domains and overall for 20 randomly selected gold pit mine sites

\begin{tabular}{|c|c|c|c|c|c|c|c|c|c|c|}
\hline $\begin{array}{l}\text { Mine } \\
\text { site } \\
\text { no. }\end{array}$ & $\begin{array}{c}\text { C\&M last } \\
\text { commenced }\end{array}$ & $\begin{array}{l}\text { Year of } \\
\text { imagery }\end{array}$ & $\begin{array}{c}\text { Mine } \\
\text { pit(s) area } \\
\text { (ha) }\end{array}$ & $\begin{array}{l}\text { Mine } \\
\text { pit(s) } \\
\text { rehab }\end{array}$ & $\begin{array}{c}\text { Waste } \\
\text { dump(s) } \\
\text { area (ha) }\end{array}$ & $\begin{array}{l}\text { Waste } \\
\text { mine } \\
\text { rehab }\end{array}$ & $\begin{array}{l}\text { Tailings } \\
\text { area (ha) }\end{array}$ & $\begin{array}{l}\text { Tailings } \\
\text { rehab }\end{array}$ & $\begin{array}{l}\text { Total mine } \\
\text { footprint } \\
\text { (ha) }\end{array}$ & $\begin{array}{l}\text { Overall } \\
\text { rehab }\end{array}$ \\
\hline 1 & 2006 & 2009 & 7 & $\mathrm{FW}, \mathrm{S}$ & 13 & $80 \%$ & 6 & $5 \%$ & 44 & $20 \%$ \\
\hline 2 & Dec-99 & 2006 & 8 & $\mathrm{FW}, \mathrm{S}$ & 30 & $60 \%$ & 4 & $10 \%$ & 65 & $20 \%$ \\
\hline 3 & May-03 & 2006 & 3 & $\mathrm{FW}$ & 13 & $10 \%$ & 4 & $0 \%$ & 31 & $15 \%$ \\
\hline 4 & Mar-03 & 2013 & 244 & PF & 429 & $30 \%$ & 133 & $5 \%$ & 1089 & $15 \%$ \\
\hline 5 & Aug-91 & 2012 & 29 & PF & 72 & $75 \%$ & 32 & $90 \%$ & 163 & $90 \%$ \\
\hline 6 & Oct-98 & 2006 & 51 & BF & 91 & $5 \%$ & $\mathrm{n} / \mathrm{a}$ & $\mathrm{n} / \mathrm{a}$ & 190 & $5 \%$ \\
\hline 7 & Jul-98 & 2005 & 3 & $P F, S$ & 3 & $10 \%$ & $\mathrm{n} / \mathrm{a}$ & $\mathrm{n} / \mathrm{a}$ & 13 & $15 \%$ \\
\hline 8 & Mar-04 & 2012 & 4 & $P F, S$ & 18 & $65 \%$ & $\mathrm{n} / \mathrm{a}$ & $\mathrm{n} / \mathrm{a}$ & 32 & $45 \%$ \\
\hline 9 & Oct-00 & 2005 & 7 & $\mathrm{BF}$ & 16 & $70 \%$ & $\mathrm{n} / \mathrm{a}$ & $\mathrm{n} / \mathrm{a}$ & 43 & $75 \%$ \\
\hline 10 & Mar-02 & 2014 & 13 & FW & 27 & $15 \%$ & 9 & $10 \%$ & 68 & $20 \%$ \\
\hline 11 & Nov-00 & 2013 & 32 & UF & 137 & $20 \%$ & $\mathrm{n} / \mathrm{a}$ & $\mathrm{n} / \mathrm{a}$ & 336 & $15 \%$ \\
\hline 12 & Jun-12 & 2015 & 8 & PF, PW & 11 & $5 \%$ & 12 & $0 \%$ & 55 & $5 \%$ \\
\hline 13 & Oct-08 & 2015 & 47 & $\mathrm{PF}$ & 129 & $20 \%$ & 51 & $5 \%$ & 379 & $5 \%$ \\
\hline 14 & Feb-00 & 2013 & 7 & $B F, S$ & 8 & $35 \%$ & 12 & $0 \%$ & 78 & $10 \%$ \\
\hline 15 & Mar-02 & 2013 & 6 & $\mathrm{FW}, \mathrm{S}$ & 9 & $45 \%$ & $\mathrm{n} / \mathrm{a}$ & $\mathrm{n} / \mathrm{a}$ & 26 & $20 \%$ \\
\hline 16 & Jun-08 & 2013 & 6 & $P F, S$ & 15 & $5 \%$ & $\mathrm{n} / \mathrm{a}$ & $\mathrm{n} / \mathrm{a}$ & 43 & $15 \%$ \\
\hline 17 & Sep-02 & 2014 & 12 & UF & 72 & $35 \%$ & 22 & $0 \%$ & 154 & $40 \%$ \\
\hline 18 & Oct-08 & 2014 & 17 & $\begin{array}{c}\text { PF, } \\
\text { PW, S }\end{array}$ & 56 & $30 \%$ & 16 & $0 \%$ & 193 & $10 \%$ \\
\hline 19 & Jun-04 & 2013 & 9 & PF & 21 & $80 \%$ & $\mathrm{n} / \mathrm{a}$ & $\mathrm{n} / \mathrm{a}$ & 40 & $75 \%$ \\
\hline 20 & Dec-00 & 2013 & 6 & FW & 33 & $40 \%$ & 11 & $5 \%$ & 75 & $20 \%$ \\
\hline
\end{tabular}

F-backfilled; PF-partly backfilled; FW-filled with water; PW-partially filled with water; UF-mostly unfilled; S-safety bunds in place

Rehabilitation effort and success tended to vary across different mining domains. Specifically, the following generalisations could be made from the spatial estimates and observations we gathered for the 20 mine sites (Table 2):

- Waste dumps - most companies had attempted rehabilitation, but revegetation was patchy and inconsistent across dumps. Many dumps were visually subject to erosion, with the sediments spreading into the surrounding vegetation.

- Although not found at all mine sites, we found little evidence of rehabilitation of tailings dams and TSFs, with most appearing to be completely bare. This may reflect the difficultly in revegetation of this novel environment given the physical and chemical stresses associated with the fine sediment in these dams (Smith et al. 2008). There were also clear breaches of these dams with sediment spreading into adjoining native vegetation.

- Mine pits/voids - these were often let to fill or partially fill with water which leads to many other management issues (McCullough \& Lund 2006). A small number of smaller pits had been fully or partially backfilled (presumably with waste material). Several sites, not all, had bunds to make these safe and reduce access by humans and livestock. 
- Other areas such as run of mine areas, lay down areas and general access and infrastructure areas within the mine site were heavily cleared in terms of vegetation and in terms of the disturbance footprint tended to cover greater areas than the mining domains outlined previously. Although these represented some of the easiest areas to rehabilitate, very little appeared to have been achieved.

Although rehabilitation was generally poor (with some notable exceptions), this is somewhat expected and logical given $C \& M$ is, by definition, a temporary phase with mining potentially recommencing at a later date (although there is no guarantee or set time frame for this to happen). Of all the C\&M sites examined in this study, about $25 \%$ had been in C\&M stage previously. To spend significant amounts of money and effort on rehabilitation where mining reoccurs is a waste of resources. However, whilst we do not advocate intensive rehabilitation on ore-bearing areas, we recommend: 1) achieving certain rehabilitation objectives in terms of making sites safe and non-polluting (to the surrounding environment); and 2) progressive restoration in areas outside main orebodies.

We believe that minimum rehabilitation targets should be established for each mining domain for mine sites going into C\&M. These could include: minimising risks to visitors and fauna through fencing and bunding; minimising erosion of surfaces through appropriate landforming and site works; preventing leaching of pollutants into groundwater; and curtailing spread of sediment/dust from the site into adjoining vegetation. Many of these remedial works will not only minimise risks whilst the mine site is in C\&M, but may also reduce the amount and costs of restorative works in the future.

There are typically large areas of major disturbance which could be rehabilitated outside of main orebodies, including run of mine and other infrastructure areas (which can be cumulatively very large areas; Table 2) and completed dumps and tailing dams. In other words, there are likely to be certain mining domains suited to rehabilitation and ideally this should be done progressively and in an integrated fashion with other mine planning and operations.

Mine pit lakes represent a pertinent example where some level of rehabilitation and water management is prudent whilst a mine is in C\&M. For instance, an open cut pit can fill relatively quickly through groundwater and surface water ingress, as dewatering is typically not continued whilst in C\&M. Water quality depending on the local geology can be poor and contaminated with toxic metals. As pit lakes at final closure are potentially one of the greatest legacies of mining, it is prudent to utilise the opportunity to test potential remediation strategies whilst in C\&M. Simply having a basic monitoring programme will substantially aid modelling of the final pit water quality. Specific actions to address water quality issues such as addition of organic matter could be trialled for low cost and provide regulators with evidence that the miner can create safe lakes at closure (Lund \& McCullough 2011). Allowing the pit to fill with water reduces the risk of land slippage below the water level due to the hydraulic head created. If mining were to resume then the water can be drained (although treatment may be required) and operations quickly re-established. Trials of remediation approaches would do little to increase the cost of re-opening the pit as the actual amount of materials added are small compared to the size of the pit. The C\&M stage also could be a prime opportunity to attend to landform and soil issues around the anticipated final high water level which will make it easier to establish riparian and fringing vegetation (van Etten 2011).

\subsection{Implications for mine closure}

In recent decades there has been a notable paradigm shift in regards to mine closure and, more broadly, the development of appropriate strategies which largely centre around community and regulator expectations, with a strong focus on environmental awareness (Mudd 2007b, 2010). Mine closure has become viewed as a paramount component of the entire mine lifecycle and is often referred to as designing for closure (Mchaina 2001), and is a dynamic process involving conceptual, feasibility and implementation phases (Van Niekerk 2014). The accompanying amendments to environmental legalisation have also assisted in mitigating some potential issues associated with mining activities, however there are notable knowledge gaps which need further refinement to strengthen the current legislative frameworks 
(Fourie \& Brent 2006). McCarthy (2015) asserts that vigorous systems need to be implemented which encompass financial and resource estimates through the life-of-mine, and this is particularly the case for gold mines which are generally subject to strongly developed boom and bust cycles due to its volatile commodity market. This overarching system would potentially result is lesser liabilities across environmental and social jurisdictions, particularly at the local community level where a mine is located. Mudd (2007b) also suggests that the gold mining sector needs to enhance its reporting and transparency which may result in better social outcomes.

Mine sites entering C\&M potentially fall between the cracks in terms of legislation, policy and current practice. They are not formally closed so many of the procedures and practices regarding mine closure do not often apply (although are meant to comply with certain conditions as outlined above). Mining can potentially recommence, but is not guaranteed, which means a lot of the key decisions around rehabilitation remain on hold which can be to the detriment to the surrounding environment and the success and ease of future rehabilitation works. As sites can remain in C\&M for several decades (Table 2), it is possible that some sites can slip into the abandoned mine category or become legacy sites over time, which means it may be too late to find a party who can be held responsible for site rehabilitation, for which the state and pubic will need to carry the can.

The environmental issues associated with gold mines in C\&M are multifaceted and gold mines in Western Australia are not immune from such issues. As a result, it is recommended that the current legal framework around sites in C\&M needs to be strengthened, and the whole mine closure process adapted to include a robust system that takes into account the environmental and social impacts of mines in C\&M. This is best achieved through open and transparent dialog with the mining industry and the Western Australian regulator (DMP). It is further suggested that a panel of experts, which can include key industry and government stakeholders, be employed to undertake this necessary and fundamental task to reduce any legacy and liabilities to the tax paying community.

\section{Conclusion}

Our research, whilst preliminary, suggests that the environmental issues associated with gold mines entering care and maintenance are multifaceted and warrant further investigation. We observed via remote sensing that the level of rehabilitation at gold mines in C\&M are variable but generally low, although we acknowledge there are significant knowledge gaps in the methods and recommend further research to improve such remote monitoring. Our research also suggests that Google Earth is a useful, versatile and effective spatial tool for conducting preliminary desk-top spatial analysis of sites in C\&M. Consequently we recommend that rehabilitation planning, implementation and monitoring of mines in C\&M be integrated within the current mine closure framework to form an all-encompassing approach, which has the ability to accurately and efficiently capture and manage the potential environmental impacts through the whole life-of-mine process. The technologies, knowledge and experience is available, we just need to implement them along with a robust system to capture and record sites in C\&M or the state may be left carrying the can.

\section{References}

ABC (Australian Broadcasting Corporation) 2015, Kalgoorlie's Super Pit, viewed 10 September 2015, http://www.abc.net.au/ science/articles/2015/03/04/4188478.htm

Abdalla, OA, Suliman, FO, Al-Ajmi, H, Al-Hosni, T \& Rollinson, H 2010, 'Cyanide from gold mining and its effect on groundwater in arid areas, Yanqul mine of Oman', Environmental Earth Sciences, vol. 60, no. 4, pp. 885-892.

Cooke, JA \& Johnson, MS 2002, 'Ecological restoration of land with particular reference to the mining of metals and industrial minerals: A review of theory and practice', Environmental Reviews, vol. 10, no. 1, pp. 41-71.

Curtis, RL \& Mousavi, A 2014, 'Gold Mining: Is It Worth Its Weight?', Environmental Forensics, vol. 15, no. 4, pp. $293-295$.

DMP (Department of Mines and Petroleum) 2009, Care and Maintenance, viewed 7 September 2015, http://www.dmp.wa.gov.au/documents/ENV-MEB-221.pdf

DMP (Department of Mines and Petroleum) 2015, MINEDEX on the Web (Public), viewed September 2015, http://minedexext.dmp.wa.gov.au/minedex/external/common/appMain.jsp 
Emel, J, Plisinski, J \& Rogan, J 2014, 'Monitoring geomorphic and hydrologic change at mine sites using satellite imagery: The Geita Gold Mine in Tanzania', Applied Geography, vol. 54, pp. 243-249.

Environment Canada 2015, Environmental Code of Practice for Metal Mines - Acts \& Regulations - Environment Canada, viewed 24 October 2015, https://www.ec.gc.ca/lcpe-cepa/default.asp?lang=En\&n=CBE3CD59-1\&offset=4\&toc=show

Fang, V, Lin, CT \& Poon, W 2007, 'An examination of Australian gold mining firms' exposure over the collapse of gold price in the late 1990s', International Journal of Accounting \& Information Management, vol. 15, no. 2, pp. 37-49.

Ferguson, A, Clinch, G \& Kean, S 2011, 'Predicting the failure of developmental gold mining projects', Australian Accounting Review, vol. 21, no. 1, pp. 44-53.

Finnie, B, Stuart, J, Gibson, L \& Zabriskie, F 2009, 'Balancing environmental and industry sustainability: A case study of the US gold mining industry', Journal of Environmental Management, vol. 90, no. 12, pp. 3690-3699.

Fourie, A \& Brent, AC 2006, 'A project-based mine closure model (MCM) for sustainable asset life cycle management', Journal of Cleaner Production, vol. 14, no. 12, pp. 1085-1095.

Gilbert \& Tobin Lawyers 2014, Issues to consider when talking a decision to put a mine on 'care \& maintenance, viewed 7 September 2015, http://www.gtlaw.com.au/wp-content/uploads/32940881_2_Gilbert-Tobin-Mining-Care-andMaintenance-December-2014.pdf

Griffiths, SR, Smith, GB, Donato, DB \& Gillespie, CG 2009, 'Factors influencing the risk of wildlife cyanide poisoning on a tailings storage facility in the Eastern Goldfields of Western Australia', Ecotoxicology and Environmental Safety, vol. 72, no. 5, pp. 1579-1586.

Hilson, G 2002, 'The environmental impact of small-scale gold mining in Ghana: identifying problems and possible solutions', The Geographical Journal, vol. 168, no. 1, pp. 57-72.

Huleatt, MB \& Jaques, AL 2005, 'Australian gold exploration 1976-2003', Resources Policy, vol. 30, no. 1, pp. $29-37$.

La Brooy, SR, Linge, HG \& Walker, GS 1994, 'Review of gold extraction from ores', Minerals Engineering, vol. 7, no. 10, pp. 1213-1241.

Lund, MA \& McCullough, CD 2011, 'Meeting environmental goals for pit lake restoration-factoring in the biology', in CD McCullough (ed.), Mine Pit Lakes: Closure and Management, Australian Centre for Geomechanics, Perth, pp. 83-90.

Kampf, SK, Salazar, M \& Tyler, SW 2002, 'Preliminary investigations of effluent drainage from mining heap leach facilities', Vadose Zone Journal, vol. 1, no. 1, pp. 186-196.

Kim, SM, Choi, Y, Suh, J, Oh, S, Park, HD, Yoon, SH \& Go, WR 2012, 'ArcMine: A GIS extension to support mine reclamation planning', Computers \& Geosciences, vol. 46, pp. 84-95.

McCarthy, B 2015, 'Rehabilitation: Obstacles and opportunities for effective life-of-mine (closure)', Australasian Institute of Mining and Metallurgy.

McCullough, CD \& Lund, MA 2006, 'Opportunities for sustainable mining pit lakes in Australia', Mine Water and the Environment, vol. 25 , no. 1 , pp. 220-226.

Mchaina, DM 2001, 'Environmental planning considerations for the decommissioning, closure and reclamation of a mine site', International Journal of Surface Mining, Reclamation and Environment, vol. 15, no. 3, pp. 163-176.

MacroTrends 2015, Historical Gold Prices - 100 Year Chart, MacroTrends, viewed 10 November 2015, http://www.macrotrends.net/1333/historical-gold-prices-100-year-chart

Mudd, GM 2007a, 'Global trends in gold mining: towards quantifying environmental and resource sustainability', Resources Policy, vol. 32, no. 1, pp. 42-56.

Mudd, GM 2007b, 'Gold mining in Australia: linking historical trends and environmental and resource sustainability', Environmental Science \& Policy, vol. 10, no. 7, pp. 629-644.

Mudd, GM 2010, 'The environmental sustainability of mining in Australia: key mega-trends and looming constraints', Resources Policy, vol. 35, no. 2, pp. 98-115.

Nobuntou, W, Parkpian, P, Oanh, NTK, Noomhorm, A, Delaune, RD \& Jugsujinda, A 2010, 'Lead distribution and its potential risk to the environment: Lesson learned from environmental monitoring of abandon mine', Journal of Environmental Science and Health Part A, vol. 45, no. 13, pp. 1702-1714.

Owens, B 2013, 'Mining: extreme prospects', Nature, vol. 495, pp. 7440 \& S4-S6.

Pritchard, J, Jensen, T \& Welsh, D 2010, 'Options for management and closure of tailings storage facilities', Engineering and Mining Journal, vol. 211, no. 2, p. 72.

Raiter, KG, Possingham, HP, Prober, SM \& Hobbs, RJ 2014, 'Under the radar: Mitigating enigmatic ecological impacts', Trends in Ecology and Evolution, vol. 29, no. 11, pp. 635-644.

Salminen, J, Blomberg, P, Mäkinen, J \& Räsänen, L 2015, 'Environmental aspects of metals removal from waters and gold recovery', AIChE Journal, vol. 61, no. 9, pp. 2739-2748.

Schueler, V, Kuemmerle, T \& Schröder, H 2011, 'Impacts of surface gold mining on land use systems in Western Ghana', Journal of the Human Environment, vol. 40, pp. 528-539.

Sijinkumar, AV, Sandeep, K, Shinu, N, Megha, V, SHyamini, C, Sreeni, KR \& Suvarna, K 2014, 'A preliminary assessment of environmental impacts due to bauxite and laterite mining in Karindalam and Kinanur, Southern India, International Journal of Conservation Science, vol. 5, no. 2.

Smith, GB, Donato, DB, Gillespie, CG, Griffiths, SR \& Rowntree, J 2008, 'Ecology of a hypersaline gold mining tailings facility in the eastern Goldfields of Western Australia: a case study', International Journal of Mining, Reclamation and Environment, vol. 22, no. 2, pp. 154-173.

Tonts, M, Martinus, K \& Plummer, P 2013, 'Regional development, redistribution and the extraction of mineral resources: the Western Australian Goldfields as a resource bank', Applied Geography, vol. 45, pp. 365-374. 
van Etten, EJB 2011, 'The role and value of riparian vegetation for mine pit lakes', in CD McCullough (ed.), Mine Pit Lakes: Closure and Management, Australian Centre for Geomechanics, Perth, pp. 91-106.

Van Niekerk, S 2014, 'Questions around mine closure: environmental engineering', Civil Engineering/Siviele Ingenieurswese, vol. 22, no. 7, pp. 45-47.

White, L 1998, 'Randol gold and silver forum'98', Engineering and Mining Journal, vol. 26. no. 199, p. 26. 